\title{
Scientific Articles' Titles: Thanks for the Information Contained in your Title
}

Etymologically, the word "title" comes from Latin titulus. The title first appears as an advertisement or even a label. A title is not about itself, but about something that is outside of it. Typically, a title should express the specific theme that determines the text. The title is often highlighted and quoted; it is not rare the cases in which the title is the only "piece" of the work known by most people. In science, only the works' titles are placed in the references, followed by the authors' names and the means of publication (journals). Thus, it will sharpen the reader's curiosity about the subject.

According to the book Thanks for the information that you didn't give me ${ }^{1}$, relevance, brevity, and simplicity are factors required for anyone who aspires to be successful with the scientific production. Due to excessive daily information, people are improving the selection of what captures their interest.

As stated by Professor Gilson Volpato, during his lectures in the postgraduation Anesthesiology course at the Medical School of Botucatu, the work's title should entice readers to read the article. He says that in today's modern world, people select what they will read by the title: if it draws their attention, they will read the abstract, and if the abstract is exciting, they will read the full article. There is an increasing tendency for people to consider "time" as their most valuable asset; therefore, reading scientific papers without relevant content is considered a waste of time. As our audience grows, we realize that the dream of producing scientific papers not only became real, but also necessary.

In another book by Volpato, Dicas para Redação Científica $^{2}$ (Tips for Scientific Writing), he suggests that the title should be short in order to be read quickly, as will often ignore long titles, and the excess of scientific articles available demands a screening of those that will be read. The author also states that the title should be faithful to the work content and should not mislead the reader: it should inform the precise content of the work, emphasizing its goal or conclusion. In general, the title must show the conclusion, the problem or the issue, and avoiding wherever possible very specific terms. This serves both the project and finished paper.

According to Professor Volpato, the title is the last step of the publication process and may be chosen to present the project to a Research Ethics Committee or even to seek in- centives for its accomplishment. Thus, the title should be simple, concise, clear, short, and impacting. The title should be a "very compressed summary" of each scientific work. If well written, it may be the main reason for someone to read what is being offered. The title has a very important function because it clarifies the matter to be discussed in the text, draws the reader's attention, instigates reading, and creates a text support.

In a recent study of article titles published in the Lancet, British Medical Journal, and Journal of Clinical Pathology in 2005, the authors showed that certain characteristics related to a paper's title guide the number of subsequent citations. Overall, there was an inverse correlation between the title length and number of citations ${ }^{3}$; other authors have suggested that many titles of scientific papers may be false or misleading ${ }^{4}$. In a recent review of dermatology journals, the authors showed that most articles did not report the study design in both title and abstract ${ }^{5}$.

While reading the Revista Brasileira de Anestesiologia (Brazilian Journal of Anestesiology), our attention is aroused by the fact that many titles are not in accordance with the content of the respective articles, and particularly by the fact that there is no consistency between several of these titles and the conclusions of the articles. Therefore, from the moment the Revista Brasileira de Anestesiologia gains notoriety, receiving articles from various countries, we should be more attentive to the titles, to encourage reading the full article and the citation of titles in order to contribute to the increase of the Journal's Impact Factor.

Both form and content equally represent the total justification of the condition and purposes of the existing project. The title is the "permanent presence" of this justification, occupying much of the time spent by readers. Finally, the title basically tautological character derives from the simple fact that its means are at the same time its end.

Luiz Eduardo Imbelloni TSA/SBA, MD, PhD 


\section{REFERÊNCIAS/REFERENCES}

1. Kestenbaum $\mathrm{N}$ - Obrigado pela informação que você não me deu. Rio de Janeiro, Elsevier, 2008.

2. Volpato GGL - Dicas para redação científica. $2^{\text {a }}$ Ed., Botucatu, 2006.

3. Jacques TS, Sebire NJ - The impact of article titles on citation hits: an analysis of general and specialist medical journals. J R Soc Med Sh Rep 2010;1:2. DOI 10.1258/shorts.2009.100020.

4. Smith J, Dunstone M, Elliott-Rudder M - Health professional knowledge of breastfeeding: are the health risks of infant formula feeding accurately conveyed by the titles and abstracts of journal articles? J Hum Lact, 2009;25:350-358.

5. Ubriani R, Smith N, Katz KA - Reporting of study design in titles and abstracts of articles published in clinically oriented dermatology journals. Br J Dermatol, 2007;156:557-559. 